This item was submitted to Loughborough's Research Repository by the author.

Items in Figshare are protected by copyright, with all rights reserved, unless otherwise indicated.

\title{
The challenge of flow: state socialist television between revolutionary time and everyday time
}

\section{PLEASE CITE THE PUBLISHED VERSION}

http://dx.doi.org/10.1177/0163443715594869

\section{PUBLISHER}

Sage Publications / @ The Authors

VERSION

AM (Accepted Manuscript)

\section{PUBLISHER STATEMENT}

This work is made available according to the conditions of the Creative Commons Attribution-NonCommercialNoDerivatives 4.0 International (CC BY-NC-ND 4.0) licence. Full details of this licence are available at: https://creativecommons.org/licenses/by-nc-nd/4.0/

\section{LICENCE}

CC BY-NC-ND 4.0

\section{REPOSITORY RECORD}

Mihelj, Sabina, and Simon Huxtable. 2019. "The Challenge of Flow: State Socialist Television Between Revolutionary Time and Everyday Time”. figshare. https://hdl.handle.net/2134/17318. 


\title{
The Challenge of Flow: State Socialist Television between Revolutionary Time and Everyday Time
}

\author{
Sabina Mihelj and Simon Huxtable, Loughborough University
}

\begin{abstract}
This article contributes to the growing literature on diverse television cultures globally and historically by examining selected aspects of television cultures in the Soviet Union and Yugoslavia. Being part of a political, economic and cultural system that self-consciously set out to develop an alternative form of modern society, state socialist television offers a particularly apposite case study of alternative forms of modern television. State socialist television was inevitably drawn into the Cold War contest between two rival visions of modernity and modern life: one premised on liberal democracy and the market economy, the other on communist rule and the planned economy. As a result, its formats, content and uses were different from those familiar from western television histories. The analysis, based on 70 life-story interviews, schedule analysis and archival sources, focuses on the temporal structures of television and on the challenges posed by television's ability to offer an instantaneous connection to the unfolding present. We argue that the nature of television temporality had ambiguous consequences for the communist project, allowing citizens of state socialist countries to disconnect from communist ideals while at the same time synchronizing their daily life with the ongoing march towards the radiant communist future.
\end{abstract}

Keywords: Television, time, modernity, flow, everyday life, communism, Yugoslavia, Soviet Union

At the core of this article lies a deceptively simple question: What is television? As Paddy Scannell has recently noted, we tend to speak of television as if it was something universal, 'as if in mentioning it anyone everywhere would know what we meant by it' (2013: 68). But do we know enough about the various forms of television globally and historically to offer a universally applicable definition of television? Scannell answers in the affirmative: for him television, in terms of content and regardless of linguistic barriers, utilises the same, universally recognisable formats and structures. For Scannell, the key to these universal features of television - and of broadcasting more generally - lies in its temporality and, more specifically, in its instant, live connection with the unfolding present. As a result of this temporality, broadcast programming is structured as a 'continuous, uninterrupted, neverending flow' (Scannell 1996: 149).

In many ways, Scannell is right in emphasising the importance of grasping the universal nature of television, above and beyond its diverse cultural, ideological and political manifestations. Yet if we are to fully grasp television as a global phenomenon, we also need an understanding of the relationship between the universal features of television, on the one hand, and the many specific, local and historical manifestations of television, on the other. Building on the growing literature on diverse television cultures globally and through history (e.g., Kraidy 2010, Evans 2010, Roth-Ey 2011, Petrierra and Turner 2013, Rivero 2015) this article seeks to show that many of the features of television familiar from television theory cannot be seen as universally applicable. Rather, they are part and parcel of a specific subtype of modern television, embedded in a particular way of being modern, tied to liberal democracy and the market economy. While this way of being modern has, by now, established itself as dominant in many parts of the world, the history of television was 
shaped by multiple visions of modernity (Eisenstadt 2000), which gave rise to multiple and often competing forms of television content and patterns of use.

This article takes the discussion about multiple modernities and diverse experiences of television further by examining selected aspects of television cultures in two state socialist countries: Soviet Union and Yugoslavia in the period from the 1960s until the end of the 1980s. As part of a political, economic and cultural system that self-consciously set out to develop an alternative form of modern society, state socialist television offers a particularly apposite case study. It was inevitably drawn into the Cold War contest between two rival visions of modernity and modern life: one premised on liberal democracy and the market economy, the other on communist rule and the planned economy. As a result, its formats, content and uses might be expected to have differed from those familiar in the west.

However, in many ways, the cultural form television took in the socialist world resembles the form familiar in the west. Above all, television became a privately owned object used within the walls of one's private dwelling, thereby fostering the kind of 'mobile privatization' Raymond Williams (1974) associated with television in the west. As Kristin Roth-Ey (2011: 23) points out, public television viewings would have fitted better with the collectivist and mobilisatory goals of the Soviet leadership than individual receivers. Instead, state socialist television became part of the bundle of home-based technologies that bridged the public and the private, with far less predictable consequences for the public life of the nation (Mihelj 2013a).

Yet if the spatial contours of state socialist television seem broadly similar to those familiar from the liberal democracies of the west can we say the same of its temporal organisation? The institutionalisation of television viewing as a private and mass activity, combined with the (in principle) never-ending flow of television programming and the distinctive potential for instant, live connection with the immediate present, meant that television became instrumental in aligning the everyday lives of private citizens with the public life of the nation. Given that the rhythms of public life in state socialist countries were tied to a significantly different vision of history, progress, and modernity than the one prevailing in the liberal democracies of the west, we might ask whether the temporal modes of everyday life fostered by state socialist television differed as well. While both visions of modernity shared a belief in progress, the communist version saw this progress as an outcome of an ongoing worker-led revolution oriented towards a distinct endpoint: Communism. As we shall show, this teleological notion of revolutionary time, coupled with the belief in a permanent revolution, sat uneasily with the repetitive rhythms of everyday life and the flow of television time. This article draws a distinction between two forms of temporality, which we call 'revolutionary' and 'socialist' time, respectively. The former refers to any temporal practice premised on the belief in the communist, teleological vision of history, beginning with revolution and ending in a communist future. Socialist time, though it includes revolutionary time, is a broader conception of temporality, which refers to any temporal practice that is distinctly socialist, whether or not it includes a belief in the communist telos.

The following section briefly reviews some of the main arguments about the temporal nature of media cultures - and broadcasting, in particular - and then outlines the main elements of the methodological approach adopted in the study, before proceeding to discuss and interpret the results. The article concludes with a general reflection on the challenges posed by the temporalities of television to establishing and maintaining a sense of involvement in revolutionary progress. We argue that the ability of television to connect audiences instantaneously to the unfolding present, and its embedding in the routine flow of everyday life had ambiguous consequences for the communist project. On the one hand, it led to a 
routinization and banalization of revolutionary temporality, and restricted the capacity of television to persuade audience that they were living in extraordinary, revolutionary times. Yet at the same time, it also contributed to stability and a sense of collective belonging in a period where communist regimes were concerned about the potential for unrest, especially after the mass protests and discontent that spread across the socialist world in the late 1960s and the early 1970.

\section{The temporalities of television}

Scannell's (1996, 2013) observations about the nature of television can be seen as an elaboration of a more long-standing discussion initiated by Raymond Williams' pioneering notes on 'flow' as the central characteristic of television both as a textual system and as a specific form of experience (1974: 77-120). In subsequent decades 'flow' became one of the core concepts in television theory, and has undergone several revisions and elaborations. John Ellis (1982), for instance, put forward a modified conceptualization that emphasized segmentation (rather than flow) as the defining characteristic of television, while Jane Feuer (1983) suggested that Williams' notion of flow is more accurately described as 'segmentation without closure' (p. 15). Horace Newcomb and Donald Hirsch (1983), on the other hand, reflected on the methodological implications of Williams' ideas, and concluded that given the flow-like nature of television, the most appropriate unit of analysis for the study of television is not the individual programme but the viewing strip.

Others, however, have been more critical of the notion of flow, and pointed out that it cannot encompass the full range of textual arrangements and viewer experiences that television makes possible (Caldwell 1995) nor can it be seen as unique to television, given its long-established presence in radio history (Boddy 1990). Some of these arguments were taken up a decade later in Paddy Scannell's (1996) and Roger Silverstone's (1994) work on the nature of modern broadcasting, which paid particular attention to its role in everyday life. According to Scannell (1996: 149), the continuous, never-ending flow of broadcast programming constituted its key 'unifying structure' and 'organizing principle'. This organising principle, he argued, impacts on both the institutional organisation of broadcasting and its connection to everyday life. Likewise, Roger Silverstone (1994: 22) has emphasized the ordinariness and dailiness of television, pointing to the profound and intimate incorporation of the medium into the fabric of everyday life, arguing that television 'is very much part of the seriality and spatiality of everyday life', and that its schedules help 'reproduce (or define) the structure of the household day', alongside the temporality of work in industrial societies. More recently, Scannell (2013) has revisited his original argument and identified television's liveness, and more specifically its immediate connection to the unfolding present, as the key to its distinctive temporal nature - another argument that revives a long-standing preoccupation with the meaning of liveness among television and media scholars.

Although thought-provoking and important at the time of their formulation, these arguments are increasingly unable to capture the growing diversity of television forms and experiences prompted by recent shifts in the technology and aesthetics of television. As several authors have pointed out, changes brought to television's temporal structures by new technologies such as the video cassette recorder (Ang 1996: 48-49),the multiplication of television channels (Richardson and Meinhof 1999: 8), and more recently the rise of digital television (Uricchio 2004), have transformed the relationship between television producers and viewers, allowing viewers to reject the pre-constituted flow of broadcast programming while also giving rise to new agents that exercise control over television flows, such as digital interface operators. 
Existing conceptualizations of television, including the notion of flow and its subsequent elaborations, have been challenged also by the growing literature examining the varied television cultures globally (e.g., Kreidy 2010, Perierra and Turner 2013, Ribeiro 2015), as well as by studies of television consumption among culturally diverse populations resulting from the encounter between global migration and transnational media. Taking the experiences of Turkish immigrants in Western Europe as a starting point, Kevin Robins and Asu Aksoy (2006: 94-96) argued that the temporal structures of broadcasting described by Scannell assume a homogeneous national media space and, as such, cannot account for trans-border media experiences. In more general terms, Anna Christina Pertierra and Graeme Turner (2013) have written about the importance of transnational and comparative analysis that rejects 'a unilateral and paradigmatic model of what television does' and instead approaches the function of television in a grounded manner that acknowledges the 'practices, routines an affordances which structure everyday life in each location', alongside the more commonly acknowledged specificities of regulatory and economic environments ( $p$. 18).

The recent literature on television cultures beyond the west has also highlighted the importance of competing visions of modernity in shaping the institutional arrangements, aesthetic forms and cultural experiences of television. In his work on Arab television, Marwan Kraidy (2010) shows how reality television served as a catalyst for controversies over how to adapt modernity in Arab societies, reigniting debates over the relationship between religion and the state, nationalism, democracy and gender roles. In a related manner, Yeidy Ribeiro's (2015) forthcoming study of commercial television in Cuba in the 1950s demonstrates that television played an important role in producing a sense of Cuban modernity, and was shaped by competing discourses of what it meant to be modern.

The analytical framework of multiple or competing modernities offers a particularly advantageous vantage point for our study; if carefully designed, it can help move the analysis beyond the simplistic opposition of the universal and the national (or the local). The competing visions of modernity, as understood here, are not seen as rooted in particular cultures or civilizations (e.g. 'Western modernity', 'Asian modernity', 'Egyptian modernity') but as tied to different political and ideological visions of what it means to be modern (e.g., liberal modernity, communist modernity). As such, they can take root in any cultural context, and provide useful tools for capturing the dialectics of the universal and the particular around the globe, without reducing the diversity of television to cultural differences alone. This means that while national television cultures constitute valid units of analysis, they do not themselves provide factors of explanation; rather, national television cultures should be seen as arenas for contests over appropriate national forms of modern social organisation, informed by competing visions of modernity that transcend cultural differences (see Mihelj 2011 for a fuller argument). Working within this framework, this article investigates the temporal structures of television and everyday life in socialist Yugoslavia and the Soviet Union, focusing on the ways in which they embodied a distinctly communist vision of time and temporal progression.

\section{Sources and methods}

To examine the temporal organisation of everyday television viewing in state socialist societies, this article draws on a combination of methodologies. The temporal practices and routines of television use were reconstructed based on 70 oral history interviews, 40 with participants who grew up in socialist Yugoslavia and 30 with participants who grew up in the Soviet Union. To capture the regional diversity of the two countries, interviews were 
conducted in different successor states; 20 each in Croatia and Serbia, 14 in Russia, 10 in Ukraine and 6 in Estonia. The sample covers three generations - those born before 1945, those born between 1945 and 1965, and those born after 65 - which coincide roughly with distinct stages of political development as well as with different phases in the introduction and spreading of television. The sample also includes a roughly even split of men and women and covers participants with different social and education backgrounds and different political preferences. The interviews consisted of two main parts. In the first part the participants were invited to recount their memories of television from earliest memories, moving through the different stages of the life cycle, following the usual techniques of oral history interviewing (e.g., Ritchie 2003) but adapted for the purpose of investigating media history (e.g., Bourdon 2003). In the second part selected excerpts were used to prompt further recollections of particular programmes and genres as well as practices of viewing and everyday life associated with them. The interviews were conducted in domestic or semipublic settings such as cafes, and lasted for about an hour.

Of course, interviews cannot be treated as transparent windows onto reality, be it the reality of past experiences, or the reality of interviewees' memories. Rather, individual recollections of past experiences are in part shaped by the particular context in which they are articulated - including the specific conversational context of the interview, and different ways of talking about the past circulating in the public realm (Mihelj 2013b). If we are to use interviews as means of accessing information about the past, we therefore need to find ways of identifying the impact of memory. To this end, we paid particular attention to the impact of public memories and the conversational context of interviews, and examined interview data alongside archival sources, newspaper and magazine articles discussing television scheduling as well as television schedules from the three leading Yugoslav TV channels (TV Zagreb, TV Belgrade and TV Ljubljana) and Central Television in the Soviet Union. This mixed methodology is used as a means of reconstructing both the temporal organisation of television programming as well as the temporal routines of everyday television viewing.

The analysis focused on identifying the shared features of state socialist television temporalities, and on using these to outline the key similarities and differences with the temporal organisation of television cultures in Western Europe and North America. The comparison between the Soviet Union and Yugoslavia offers a particularly strong basis for identifying the shared traits of state socialist television cultures; while the media system of the Soviet Union served as a key reference point for communist-led countries worldwide, the Yugoslav media system - being part of a communist country that distanced itself from the Soviet Union in 1948 and sought to carve its own way into communist modernity - arguably moved furthest away from the Soviet template. Differences between the two countries are mentioned only in passing, as are changes over time as well as distinct generational, gender and other patterns of television viewing emerging from the analysis. The bulk of material presented here relates to the period of so-called 'mature' or 'late' socialism, extending roughly from the late 1960s to the mid-1980s. This period coincided with the most rapid development of television and its establishment as the dominant means of mass communication in both countries. The presentation of results focuses on two key dimensions of television temporalities identified in the materials: one tied to the rhythm of clock time, daily life and weekly cycles, the other to the rhythm of the calendar year and the succession of seasons. These two dimensions correspond broadly to two crucial aspects of the temporal organisation of everyday life and broadcasting identified in literature - clock time and calendar time (Scannell 1996, O'Sullivan 1991) - as well as to two prominent types of television memories - 'wallpaper' memories, consisting of recollections of routine viewing, and memories of media events (Bourdon 2003). As we shall see, both of these temporal 
structures display similarities with the temporal structures familiar from the liberal democracies of the west, yet also contain some distinctive features. These features were designed to tie the rhythms of clock and calendar time to the passage of revolutionary time, premised on the belief in an on-going revolutionary progress.

\section{The rhythms of clock time: daily and weekly routines}

Daily and weekly routines of engagement with television in state socialist societies were structured around rhythms of work and leisure, with programmes scheduled to coincide with times of the day and week when the majority of the population was free from work: evenings and weekends. While existing research on television cultures in the liberal democracies of the west is too limited to make a sound assessment of 'western television' in general, available sources (e.g. for Britain Scannell 1996, O'Sullivan 1991, Gauntlett and Hill 1999: 23-34; for France Chaniac and Bourdon 1990) suggest that the general structures of television clock-time were similar in this regard. This pattern was particularly visible in Yugoslavia, where Sunday television programmes were significantly longer than those available on working days and Saturdays. On a typical working day in the late 1960s, for instance, Yugoslav TV schedules consisted of a block of morning programming between 9 am and noon and a second block that started between 3 and 6 pm and finished between 10 and 11p.m. In contrast, Sunday programmes started in the morning and lasted through most of the day. In the Soviet Union, the contrast between Sunday and working day schedules were less marked, with programmes in the late 1960s running from around 3.30pm four days a week, and from 12 noon two days a week, while Sunday programmes started only marginally earlier - at 11.30am. By the mid-1970s, the gap between weekdays and Sundays disappeared altogether, but it is worth noting that the content of Sunday morning programmes was markedly different from the content of weekday morning programmes, and included many of the country's most popular shows.

Interviewees' recollections confirm the familiar interweaving of television viewing and work rhythms. Several interviewees remembered the routine family viewing of television during late afternoons and evenings, after everyone was back home from work. As one participant from Serbia explained:

Everyone was watching, which means I was watching as well until the final news bulletin. [...] The programme started at $6 \mathrm{pm}$ and ended at $10 \mathrm{pm}$, and you were watching non-stop. (YuSrb-15, 1947)

Contrary to what one might expect from participants who grew up in communist-led societies, almost none of the participants mentioned watching prime time programmes explicitly designed to promote a sense of revolutionary time. This may have been an artefact of selective memory, but it also reflected the actual lack of this type of programming on prime time television. Even though references to the persuasive powers of television regularly featured in public debates about the medium, prime time schedules in both countries were filled with light entertainment and news programmes rather than messages explicitly designed to mobilise the population. Explicit 'propagandistic' programmes did exist of course, yet they were typically scheduled outside peak viewing times. For instance, Soviet Central Television reserved the weekday slot between 6:30 and 7pm for a continuing education programme called 'Leninist University of Millions' on Mondays and Tuesdays, and 'Problems of Agriculture' on Wednesdays and Thursdays (Evans 2010: 74).

This does not mean that television professionals were unaware of the importance of synchronising television schedules with daily routines, or of the possibility of imposing 
desirable content on audiences during peak viewing times. As an internal document discussing programme policies for TV Belgrade in 1967 stated, 'Drawing on the habits of viewers and their rhythms of life, television [...] can impose certain contents, and by manipulating time it can guarantee a relatively high level of audience' (RTS-CPOPAR 1966: 8). Yet the same report warned that such 'manipulative' use of scheduling could easily alienate audiences, and instead argued that scheduling had to take into account viewers' preferences and ensure that prime time slots were reserved for programmes with the widest appeal: entertainment and news programmes (RTS-CPOPAR 1966: 9). Similar debates (with similar conclusions) took place in the Soviet Union (Evans 2010: 72-78). Such scheduling practices suggest that reaching and retaining a mass audience took precedence over delivering the most desirable messages, or was at the very least seen as equally important. As a result, prime time schedules and viewing routines shared many of the basic patterns familiar from Western European and North American television history, and appear far removed from a distinctly communist, revolutionary sense of temporal organisation.

Of course, individual information and entertainment programmes scheduled during prime time offered plenty of less conspicuous opportunities for tying the quotidian to the grand narrative of communist modernity and progress. Daily news bulletins, for instance, functioned as regular reminders of the continued unfolding of revolutionary time, informing audiences of the major milestones in the on-going struggle for progress and worker equality, exemplified by technological and industrial achievements, Party meetings and decrees, or glamorous visits of domestic leaders to foreign countries. Yet judging from our interviews, such glimpses of revolutionary time rarely functioned as effective ways of mobilising audiences. There were some exceptions, especially among Soviet interviewees, but on the whole, as the excerpt quoted earlier indicates, daily news bulletins are remembered primarily as part of taken-for-granted routines - something everyone had to watch - rather than as inspirational programmes that enhanced a sense of participation in revolutionary achievements.

From a temporal perspective, the act of embedding glimpses of revolutionary progress into the news format arguably had profound implications for the nature of audience relationships with the unfolding of revolutionary time. As part of daily routines, these items lost their revolutionary aura, and became a part of the repetitive, unremarkable flow of daily life. As one interviewee said of the Soviet news programme Time': 'When I was young, maybe until I was 30, I wanted it to finish, because it was very dreary [...] You had the feeling that how much farmers sowed, how much grain they yielded, it had no ... I felt that it didn't have any connection to my life.' (USSR-6, 1960). Oriented towards a glorious future and premised on constant change and on-going mobilisation, communist revolutionary time sat uneasily with the mundane, repetitive movement of everyday life. The routinisation of communist belonging and temporality therefore undermined the features that were central to the continued survival and success of the communist cause, namely, permanent progress. The attempt to embed revolutionary time in the genre of news presented Soviet news producers with a virtually insurmountable challenge. The attractiveness of news was rooted in its ability to offer an instantaneous connection with the present, and to bring stories of unexpected, unpredictable developments. Yet the communist vision of history and modernity and the specific criteria for newsworthiness they generated left little room for the unexpected; instead, the key task was to represent the unfolding of a future that was already known and predictable (Evans 2010: 86-114). To put it differently, the liveness of television - the very core of its distinctiveness according to Scannell (2013) - banalised the revolution and thereby undermined the sense of progress towards Communism. 
But while the repetitive, quotidian flow of broadcasting evidently posed problems for state socialist television, it did not altogether preclude the establishment of a distinctly socialist temporal structure of television. Firstly, communist elites saw television as an important aspect of 'cultured' leisure. Newspapers and magazines criticised viewers who watched television indiscriminately, arguing that there should be a balance between television viewing and other cultural activities (Roth-Ey 2011: 199-208). Perhaps as a result, viewers prized attentive over distracted viewing: they remember having tuned in to watch specific, often pre-selected, programmes, rather than leaving the television running in the background (a practice which many Russian interviewees considered to have arrived after the fall of Communism). In this respect, socialist television viewing practices challenge the equation of television with 'flow', suggesting that different political cultures could breed different ways of engaging with television. Secondly, a distinct sense of the passage of time could also be created by omitting particular programmes from the schedule. Once we take these factors into account, it becomes apparent that daily and weekly schedules of state socialist television did contain distinctive elements, including the prominence of educational content, the lack of gendered programming in daytime schedules on workdays, and the secular nature of Sunday daytime programming.

Daytime schedules in both Yugoslavia and the Soviet Union significantly differed from those in the west. In the Soviet case, daytime TV largely consisted of repeats of the previous evening's prime time schedule. This was designed to ensure that both schoolchildren and workers on the late shift didn't miss the previous day's programming. As one interviewee joked, aping one of the Party's most ubiquitous formulations, this was the regime's 'concern for workers' in action (USSR-1, 1974). In the Yugoslav case, the daytime schedule mostly consisted of educational programming interspersed with cartoons and news programmes. In both cases the target audience of such shows tended to ignore two potential groups of viewers: retirees and (to a lesser extent) housewives, the latter of which was central to daytime schedules in Western Europe and North America.

The message of daytime content was therefore clear: this was a time for work, or at the very least a time for education and attainment of new skills and knowledge that would aid the country's onward progress. Many of these educational broadcasts were explicitly timed to fit in with the passage of the school year, with TV guides printing 'lesson plans' of scheduled broadcasts in late August, before the beginning of term. One Soviet interviewee remembered the educational slant of socialist daytime TV clearly:

On the whole I think that the function of television was always more educational [... A]s soon as I came back from school we were interested in anything educational. And if on Channel One everything was very alike, the news was all the same, then in the morning the function of Channel Two was educational, absolutely. (USSR-1, 1974)

Yugoslav interviewees (particularly those with higher educational backgrounds) remembered educational television especially fondly:

Television ushered in a whole new era of life for us [...]. Because in our home, since people were not stupid and wanted to learn and so on, dad told us: 'Children, you need to learn and get to know more so that you won't have as difficult a life as I did'. This was, I don't know ... the beginning and the end of the whole story about education. And they were really making an effort although they weren't well educated, but they understood that watching television was of great importance. (Yu-Cro-05, 1957)

The role of television in furthering education and offering access to cultural experiences beyond one's immediate environment also featured prominently in the west, especially in 
the context of public service broadcasting. The absence of detailed analyses of the temporal organisation of public broadcasting precludes us from drawing firm conclusions, but tentatively speaking we can argue that the position of educational content in state socialist television schedules was more prominent, or at least remained prominent for longer. Also, televised education on socialist television was combined with the near absence of daytime entertainment programming (except in the case of repeats), as well as a comparative lack of daytime content designed for female audiences. This specifically socialist temporal organisation can be seen as an important part of a distinct culture of television viewing, linked to the communist ideal of modern society and culture. This ideal, centred on the figure of the cultured and educated worker, promoted an understanding of daytime as time dedicated to the construction of a common communist future, whether by means of work or education.

If daytime programme represented one distinctive element of socialist television temporality, the secular nature of viewing routines forms a second. This is of course hardly surprising for a political system where religion was effectively banned from the public sphere, and where membership in the Communist Party was seen as incompatible with open religiosity. The distinctive secular nature of state socialist temporality became particularly apparent on Sunday mornings. Unlike television schedules in the west, which often featured live transmissions of religious ceremonies or dedicated religious programmes such as the BBC's Songs of Praise or RAl's weekly broadcasting of the Sunday service, Sunday mornings in Yugoslavia and the Soviet Union included no reference to weekly religious rituals. Instead, they featured children's entertainment programmes, special programmes dedicated to farmers and army officers and soldiers, and a number of popular shows about cinema and travel: a distinctly socialist prime time. Sunday children's programmes are particularly fondly remembered by our participants from both countries, and although their secular character is hardly ever recognised as such, there is reason to believe that they constituted an attractive alternative to the Sunday mass for young television viewers. This competition between the temporal structures of religious life and the temporal organisation of state socialist television comes clearly to the fore in the following quote from a woman who grew up in Yugoslavia:

Something I remember most vividly from 1967 were the serial programmes that were broadcast on Sunday mornings at 10am, usually of foreign production. [...] But we were going to church, and we went to church every Sunday. And mum said: You have to go to church', so that she could have a bit of peace and quiet and cook lunch [...] But the mass was starting at $10[\ldots]$ and we were always late. And then we agreed with mum that we no longer want to attend the big mass and instead went to the mass early in the morning at 8 to this small church so that we were ready for the serials films for children. (Yu-Cro-05, 1957)

The existence of Sunday programmes designed to address farmers and soldiers in both countries can also be interpreted within the secular temporal logic. Farmers were more likely to be more religious than urban dwellers, and an attractive Sunday programme could serve as a tempting alternative to religious services. The special care invested in making these programmes attractive for a broad audience - by including intervals of folk dancing and singing in the Soviet case (Evans 2010: 77), and scheduling them in conjunction with folk music programmes in Yugoslavia - also indicates that a key aim of broadcasters in both countries was to attract a wide audience rather than deliver a particular message. Similar strategies were employed with respect to Sunday programmes dedicated to the army. In the Soviet Union, such programmes were typically scheduled to follow or precede popular children's programmes, or included popular segments such as dedications and song requests by soldiers and their families (Evans 2010: 77). In the Yugoslav case, similar scheduling practices were employed with regard to the military-based programme 'Allow Us to Address You', which was broadcast in conjunction with popular war films and children programmes. 
As excerpts from several interviews suggest, scheduling doubtlessly played a role in enhancing the programme's popularity. As one interviewee noted: 'One programme I always watched on Sundays was 'Allow Us to Address You'. Of course not the programme about how to charge and discharge an M48 but I was devouring the film' (Yu-Srb-07, 1969).

Arguably, the secular nature of Sunday programming, along with the emphasis on educational content and the lack of entertainment and women's programming on daytime television, played an important role in establishing a distinctly socialist structure of television time. Though audiences could appropriate these structures in different ways, their mere presence created a recognisable set of temporal hierarchies that privileged certain activities over others. However, as with attempts to use news bulletins to connect viewers with the revolutionary passage of time, such scheduling practices did not necessarily succeed in instilling explicit awareness of it. Instead, they fostered participation by privileging particular everyday activities that were thought to be essential components (education, work, army service), and displacing others (attendance of religious services). This had ambiguous consequences for the communist project. On the one hand, the specifically socialist temporal routines encouraged by television to some extent managed to change the practices of everyday life, and made involvement in the revolution a matter of taken-for-granted routine for many. On the other hand, it is not clear whether such routinization of the revolution was paralleled by a conscious commitment to the communist cause. In other words, television was more successful in creating a sense of a shared socialist temporality than a revolutionary one.

\section{The rhythms of calendar time: seasonal cycles and festive programming}

As with daily and weekly routines, the seasonal structures of television scheduling and viewing in Yugoslavia and the Soviet Union shared some common traits with temporal structures found in the west. The rhythms of television time followed the cyclical succession of seasons, with programme planners trying to find 'broadly appropriate seasonal matter to suit the climate of the time of year and the mood and leisure activities of the audience', with the winter months, for instance, being generally reserved to more 'serious' content (Scannell 1996: 154-155). At the start of every autumn, winter holiday season, and summer, Yugoslav broadcasters would announce the key highlights of the upcoming seasonal schedule, often focusing on improvements compared to the previous year. For instance, in May 1967, the Programme Committee of Yugoslav Radiotelevision announced several improvements to the summer schedule, due to start in J une, designed to tailor the programme to the wishes and needs of the widest possible range of viewers' (TV Novosti 1967). Highlights included a far greater total of broadcast hours compared to the previous years, more sports coverage and a feature film every Tuesday and Friday.

Interviews include remarks that confirm the seasonal cycles of viewing routines, with summer months often spent with family members in the country or in holiday resorts with plenty of outdoor and social activities to lure viewers away from television sets. By contrast, interviewees - especially those born in the 1960s and 1970s - clearly remembered times spent in front of television sets during winter holidays - a time when television studios across the country would complement the usual educational content of daytime schedules with cartoons, films and serial programmes aimed specifically at school children. As one of the interviewees who grew up in the Soviet Union recalled, 'when it was dark and cold then I watched TV and I think that in the weekends and during holidays I watched twice as long as normal days. At least.' (USSR-25, 1971) 
While the seasonal rhythms of the Yugoslav and Soviet television calendars broadly corresponded to those familiar elsewhere, the rhythm of festive programming, tied to major holidays, was set to a distinctly socialist tune. In contrast to Western Europe or North America, this rhythm was out of sync with the religious calendar and was instead organised around secular holidays designed to commemorate the revolutionary achievements of the past and anticipate the fulfilment of communist ideals in the future. Two of the central moments in this calendar year, which were accompanied by major state celebrations and holidays lasting for several days - Labour Day in early May, and the New Year in late December and early J anuary - were shared by state socialist countries globally, and formed part of a transnationally shared sense of the passage of time that sought to rival the religiously infused ones prevailing in the liberal democracies of the west (for holidays and mass festivals in the Soviet Union see e.g. Baiburn and Piir 2011; for China, Hung 2007).

Moreover, as one of the central mass media of the post-war decades, television played a major role in instilling this shared sense of the past. It did so by giving rise to new rituals and 'invented traditions' (Hobsbawm and Ranger 1983) that tied public celebrations and state festivities to the myriad of local, family-centred rituals in the private domain (Thompson 1995: 179-206). However, it is important to note that, while the intention of such festivals was to connect viewers with the flow of revolutionary time, these festivities neither possessed a particularly pronounced ideological content, nor were they necessarily seen as 'socialist' by the audience. New Year programmes, in particular, were largely devoted to entertainment and included few explicit references to the communist past or future. The two central television programmes of the Soviet New Year - Little Blue Flame (1962-present), a variety show featuring popular performers and public personalities, and Song of the Year (1971-present) a popular music contest - were both designed to respond to the popular demand for entertainment, and centred on humour and popular music (Evans 2011). Likewise, the New Year schedules of Yugoslav television channels revolved around a central variety show consisting of comic sketches and dance and music performances specifically designed for the show by popular actors and musicians, preceded by feature films and festive episodes of popular television series. The same programmes were also emphasised in the announcements of New Year television schedules published in the popular press, which promised viewers a festive season full of humour and light-hearted music, with little reference to news or documentary programming (TV Novosti 1972a, 1978).

Entertainment programmes were also at the forefront of our interviewees' recollections, who often mentioned the role of the small screen as an integral part of New Year festivities:

My parents often went over to some neighbours where a whole group would get together. Children also went along, we played there, while they watched [...] and there were interesting songs from different regions, and people were celebrating, singing, and everything was very jolly. (Yu-Cro-11, 1964)

There were festive pies on the table and a broadcast of the demonstration in Moscow on May 1, November 7 ... oh, and of course, 'Little Blue flame' - at New Year it was almost obligatory [laughing] we didn't conceive of it that we could miss these festivals. (USSR-11, 1952)

Despite the largely apolitical nature of New Year programmes, these television festivities much like the Sunday programmes discussed in the previous section - contributed to the establishment of a markedly secular temporal order. While the New Year was a highly significant date for socialist and capitalist nations alike, socialist television was distinctive in its privileging of New Year's Day over Christmas Day, and its lack of religious content. As a result, socialist television festivities helped to generate a publicly-acknowledged hierarchy of temporal preferences, marking secular New Year festivities as a key element in the calendar 
year while displacing the importance of religious festivals. These temporal preferences did not necessarily erase the religious temporalities in the private realm altogether, but they doubtlessly limited the opportunities for their public expression and validation. As one interviewee commented:

At that time we celebrated practically all Soviet festivals. The thing is [...] that at that time religious festivals were not permitted. [...] Christmas, Easter - it wasn't permitted ... It was all forbidden, especially because my parents were teachers. We celebrated them at home, but ... on the sly. But we openly celebrated only Soviet festivals - so Victory Day, 1 and 2 May, 23 February, 8 March. (USSR-12, 1960)

In contrast to New Year's Day, the other major holidays mentioned here were far more explicitly linked to the communist vision of history and progress. In the Soviet Union, these included Red Army and Navy Day (February 23), Women's Day (March 8), Labour Day (May 1) and Victory Day (May 8). In Yugoslavia, the major points in the calendar year were Labour Day (May 1), Youth Day (May 25) and the Day of the Republic (November 29). As with the New Year, entertainment programming featured prominently in television schedules on these holidays, but was combined with a significantly greater proportion of programmes designed to foster a sense of celebratory involvement in revolutionary progress, either by celebrating the glorious achievements of the past or by staging the on-going march towards a radiant future.

From an audience perspective, however, the festive revolutionary rituals encouraged by television largely became emptied of revolutionary meaning. That is not to say that they were not experienced as 'special' in some way, but at the same time, they were hollowed out. As interviews suggest, the sense of excitement and pleasure associated with festive television programming was primarily down to its entertainment content rather than explicit political messages. The following excerpt is typical in this respect:

\begin{abstract}
Yes, we were watching [television] because on holidays they usually had a richer programme and there were films during the day [...] Usually they were broadcasting good war films for these holidays, and I could watch those a hundred thousand times. [...] There would be films from the morning onwards, which didn't happen on working days. So I loved these holidays, there were always some good domestic films and sometimes a foreign one. And for the evenings they were also saving us special episodes of some series, so that they also had some kind of holiday and it was a kind of special episode. (Yu-Srb-02, 1946)
\end{abstract}

Festive programming typically achieved high audience ratings, and features among the most fondly remembered elements of television experiences among our interviewees, demonstrating the effectiveness of festive programming in securing popular participation in celebrating the revolutionary passage of time. Yet there is little to indicate that the enthusiasm accompanying this participation was coupled by a commitment to the communist cause, or a belief in one's own contribution to revolutionary progress.

\title{
Conclusions: The ambiguous consequences of television flow
}

Despite notable similarities with the temporal organisation of television cultures in the west, state socialist television followed distinct rhythms of clock and calendar time. Firstly, the daily and weekly routines of daytime broadcasting privileged education, following the recognisably communist vision of culture as an instrument of progress and education rather than entertainment and leisure. While a similar emphasis on educational content can be found in the context of western public broadcasting - a parallel that merits further empirical 
examination - it was possibly more pronounced in the state socialist context, and was also combined with a near absence of gender-specific daytime programming. Secondly, both clock and calendar times of state socialist television were markedly secular; as we have shown, Sunday schedules and New Year festivities offered attractive alternatives to religious rituals, and marginalised the temporal organisation of everyday life associated with the religious week and year. Finally, television encouraged popular commemoration of the revolutionary passage of time, especially during major holidays.

Given the size of the sample, our interviews cannot be used to reliably gauge the extent to which television audiences in state socialist countries accepted the temporalities embedded in television schedules, and weaved them into the fabric of their own everyday routines. Yet they do at the very least demonstrate a shared awareness of these temporalities, if not always their actual acceptance at the level of actual temporal organisation of everyday life.

One key question concerns television's role in outlining a distinct socialist temporality. Did the prominence of calendar time over revolutionary time presupposed by television's 'liveness' prompt a crisis of revolutionary momentum, or a transition to a new form of temporality in the period of so-called 'late Socialism'? This article provides evidence for both readings. More than any other component of the socialist mass media ensemble, television became a part of the fabric of the socialist quotidian. But the repetitive, taken-for granted nature of these everyday rhythms sat uneasily with the out-of-the-ordinary revolutionary temporality underpinning the communist narratives of heroic past and glorious future.

The case of festive television provides a case in point. The distinct rhythms of television time in state socialist countries were most pronounced during these occasions, especially those associated with celebrating the secular movement of time (the New Year) or commemorating the glorious victories of the past (e.g. Day of the Republic in Yugoslavia, or Victory Day in the Soviet Union). But our interviews suggest that citizens focused less on revolutionary progress towards the future and more on the comforting sense of continuity that these rituals provided. As one Russian respondent said of New Year TV: 'the family is still here; a year has passed. Nobody has ... disappeared, died. Everything's fine.' (USSR-9, 1962).

Ultimately, the constant flow of television and its ability to connect audiences to the unfolding present - the very core of its distinctiveness according to Scannell (2013) seemed to undermine a sense of active participation in the march of communism. Television allowed citizens of state socialist countries to disconnect from the communist project while at the same time synchronizing their daily life with the ongoing march towards the radiant communist future. In this sense, its consequences were ambiguous: television created a sense that viewers were living in socialist time, but it is unclear whether this was accompanied by a desire to actively build the communist future.

\section{Bibliography}

Ang, I (1996) Living Room Wars: Rethinking Media Audiences. London: Routledge.

Baiburn A and Piir A (2011) When We Were Happy: Remembering Soviet holidays, in Balina M and Dobrenko E eds. 2011. Petrified Utopia: Happiness Soviet Style (London: Anthem Press). 
Boddy, W (1990) Fifties Television: The Industry and Its Critics. Urbana: University of Illinois Press.

Bourdon J (2003) Some Sense of Time: Remembering Television. History \& Memory 15(2): 5-35.

Caldwell, JT (1995) Televisuality: Style, Crisis and Authority in American Television. New Brunswick, NJ: Rutgers University Press.

Chaniac R and Bourdon, J (1990) L'Europe au prime time, Médiaspouvoirs 20: 145-52.

Eisenstadt SN (2000) Multiple Modernities, Daedalus, 129(1): 1-29.

Ellis, J (1982) Visible Fictions: Cinema, Television, Video. London: Routledge.

Evans CE (2010) From Truth to Time: Soviet Central Television, 1957-1985, Unpublished doctoral thesis, UC Berkeley. Available at: http://escholarship.org/uc/item/2702x6wr.

Evans CE (2011) Song of the Year and the Soviet Mass Culture of the 1970s, Kritika: Explorations in Russian and Eurasian History, 13(2), 617-645.

Feuer, J (1983) The Concept of Live Television: Ontology as Ideology, in Kaplan, A (ed) Regarding Television. Los Angeles, CA: American Film Institute, 12-22.

Gauntlett D and Hill A (1999) TV Living: Television, Culture and Everyday Life. London: Routledge.

Hobsbawm E and Ranger T (eds) (1983) The Invention of Tradition. Cambridge: Cambridge University Press.

Hung C (2007) Mao's Parades: State Spectacles in China in the 1950s, The China Quarterly, 190: 411-431.

Kraidy M (2010) Reality Television and Arab Politics: Contention and Public Life. Cambridge: Cambridge University Press.

Mihelj S (2011) Media Nations: Communicating Belonging and Exclusion in the Modern World. Basingstoke: Palgrave.

Mihelj S (2013a) The Politics of Privatization: Television Entertainment and the Yugoslav Sixties, in Gorsuch, A and Koenker D (eds.) The Socialist Sixties: The Global Movement in the Soviet Union, Eastern Europe, and Cuba. Bloomington, IN: Indiana University Press, 251-267.

Mihelj S (2013b) Between Official and Vernacular Memory, in Pickering M and Keightley E. (eds.) Research Methods for Memory Studies. Edinburgh: Edinburgh University Press, 60-78.

Newcomb, HM and Hirsch, PM (1983) Television as a Cultural Form: Implications for Research. Quarterly Review of Film Studies 8(3): 45-55.

O'Sullivan T (1991) Television Memories and Cultures of Viewing, 1950-65, in Corner J (ed) Popular Television in Britain: Studies in Cultural History. London: BFI, 159-82.

Pertierra AC and Turner G (2013) Locating Television: Zones of Consumption. London: Routledge. 
Petrie D and Wills J (eds) (1995) Television and the Household: Reports from the BFI's Audience Tracking Study. London: British Film Institute.

Richardson K, and Meinhof U (1999) Worlds in Common? Television Discourse in a Changing Europe. London: Routledge.

Ritchie, DA (2003) Doing Oral History - A Practical Guide. Using Interviews to Uncover the Past and Preserve it for the Future. Oxford: Oxford University Press.

Rivero YM (2015) Broadcasting Modernity: Cuban Commercial Television, 1950-1960. Durham, NC: Duke University Press.

Robins K and Aksoy A (2006) Thinking Experiences: Transnational Media and Migrants' Minds, in Curran J and Morley D (eds) Media and Cultural Theory. London: Routledge, 8699.

Roth-Ey K (2011) Moscow Prime Time: How the Soviet Union Built the Media Empire That Lost the Cultural Cold War. Ithaca: Cornell University Press.

RTS-CPOPAR (Radio-Television of Serbia, Centre for Public Opinion, Program and Audience Research). 1966. Report 161, Programska politika TV Beograd u 1967. godini.

Scannell P (1996) Radio, Television and Modern Life: A Phenomenological Approach. Oxford: Blackwell.

Scannell P (2013) Television and the Meaning of Live: An Inquiry into the Human Situation. Cambridge: Polity.

Silverstone R (1994) Television and Everyday Life. London: Routledge.

Thompson J (1995) Media and Modernity: A Social Theory of the Media. Cambridge: Polity.

Uricchio, W (2004) Television's Next Generation: Technology/Interface culture/Flow, in Spiegel L and Olsso J (eds) Television after TV: Essays on a Medium in Transition. Durham, NC: Duke University Press, 163-182.

Williams R (1974) Television: Technology and Cultural Form. London: Fontana.

TV Novosti (1967) Od juna: igrani filmovi utorkom I petkom, TV Novosti, May 1967, p. 13.

TV Novosti (1972) Less Luxury, More Entertainment, TV Novosti, 29 December 1972, p. 7.

TV Novosti (1978) Good Evening, Good People, TV Novosti, 29 December 1978, p. 7. 